\title{
The Sickle-cell and Altitude
}

\author{
R. L. GREEN, R. G. HUNTSMAN, G. R. SERJEANT
}

British Medical fournal, 1971, 4, 593-595

\section{Summary}

High altitude seemed to be responsible for seven recent cases of sickling crisis. People with sickle-cell trait are at risk if they fly in unpressurized aircraft, which are used for many local air services. Those with sickle-cell haemoglobin C disease should avoid air travel even in pressurized aircraft. Possibly as a result of "autosplenectomy," patients with sickle-cell anaemia seem to be able to fly in pressurized aircraft with little risk. All passengers and aircrew who might have some form of sickle-cell disease should be screened before flight.

\section{Introduction}

The term "sickle-cell disease" covers a number of genetically distinct conditions of variable clinical severity which have in common the presence of sickle haemoglobin in the red cell. Sickle haemoglobin, being relatively insoluble in the reduced form, is capable of distorting the red cell into characteristically sickle-shaped cells. These cells obstruct small blood vessels leading to scattered painful infarcts.

The sickle-cell trait is the carrier (or heterozygous) state which occurs in about $20 \%$ of West Africans and $10 \%$ of West Indians and American Negroes. These people are generally fit and sickling occurs only under conditions of severe hypoxia. The term sickle-cell anaemia should be reserved for the clinically severe homozygous state characterized by a chronic anaemia and recurrent infarctive episodes. Patients with sickle-cell haemoglobin $C$ disease are often fit. They are nevertheless liable to occasional infarctive crises, which, when they occur, may prove fatal. It is not unusual for an adult to be unaware that he suffers from this disorder. Sickle-cell thalassaemia is less severe than classical sickle-cell anaemia. Patients suffer from a chronic haemolytic anaemia and may have a variable number of infarctive crises. The other forms of sickle-cell disease are rarely encountered.

Hypoxia sufficient to cause an infarctive sickling crisis may occur during infections or anaesthetic accidents, and the risks of these situations are documented (McCormick, 1961; Thompson, 1963; Konotey Ahulu, 1969). A subject may also become hypoxic by flying or residing at high altitude, the arterial oxygen pressure at ground level and 5,000 and 10,000 ft (1,525 and 3,050 m) being about 100,70, and $55 \mathrm{~mm} \mathrm{Hg}$ respectively (Sluijter, 1969). The degree of hypoxia experienced at high altitude in unpressurized aircraft may precipitate infarctive crises even in the benign sickle-cell trait. Hypoxia caused by a combination of violent exercise and residence at a moderately high altitude $(4,000 \mathrm{ft} ; 1,220 \mathrm{~m})$ has also been recently reported as capable of precipitating a fatal sickling crisis in sickle-cell trait carriers (Jones, Binder, and Donowho, 1970). However, no sickling crises were reported among the African competitors with the

Passenger Services, Air Corporation Joint Medical Service, Heathrow, Middlesex

R. L. GREEN, M.B., CH.B., D.AV.MED., Medical Officer

St. Thomas's Hospital Medical School, London S.E.1

R. G. HUNTSMAN, M.D., M.R.C.PATH., Reader in Haematology

Department of Medicine, University of West Indies

G. R. SERJEANT, M.D., M.R.C.P., Wellcome Research Fellow (Present address : Abnormal Haemoglobin Unit, Department of Biochemistry, University of Cambridge) sickle-cell trait competing in the Mexican Olympic Games at $7,000 \mathrm{ft}(2,135 \mathrm{~m})$ (A. E. Romero-Herrera, personal communication, 1970).

Modern airliners are partially pressurized and the problems associated with the transport of cardiac and respiratory patients under these conditions have already been extensively reviewed (Beighton and Richards, 1968). However, with the increasing frequency of air travel among Negroes in the United States, Africa, the West Indies, and the United Kingdom, it becomes important to assess the risk of pressurized flying in the various types of sickle-cell disease.

Seven recent examples of sickling crises in flight are reported. One involved a sickle-cell trait carrier in an unpressurized aircraft and another describes a sickling crisis, possibly precipitated by air travel, associated with a visit to a high altitude.

\section{Case Reports}

Case 1.-A 20-year-old Ghanaian nurse flying in an unpressurized aircraft at about $10,000 \mathrm{ft}(3,050 \mathrm{~m})$ from Kumasi to Accra developed acute abdominal pain in flight. On arrival she was admitted to hospital with severe pain and board-like rigidity of the whole abdomen. On laparotomy the only abnormality found was a small area of plum-coloured congestion of the small bowel and some straw-coloured clear fluid in the peritoneal cavity. There was no splenomegaly and no gross evidence of splenic infarction. She made an uneventful recovery from what is presumed to have been an infarctive incident in the small bowel. Haemoglobin studies later showed that she was a sickle-cell trait carrier.

Case 2.-A 34-year-old American negro woman, who was thought to have sickle-cell thalassaemia, travelled on a flight in a pressurized airliner between New York and Trinidad. The airline had been warned that she might need prophylactic oxygen, which was given during the flight. Despite this, she suffered from a severe attack of bone pain, which, the crew reported, was extremely distressing to both her and the other passengers who witnessed it. After family studies she was subsequently diagnosed as having sickle-cell anaemia.

Case 3.-A 22-year-old Nigerian man developed severe pain in the left hypochondrium two hours after leaving Lagos on a flight to London in a pressurized aircraft. There was no history of previous illness. The aircraft was flying at about $35,000 \mathrm{ft}$ $(10,670 \mathrm{~m})$ and the cabin altitude was a little over $5,000 \mathrm{ft}(1,525 \mathrm{~m})$. On arrival in London he was still in considerable pain, with a tender enlarged spleen and a slight pyrexia. Splenic tenderness and pain resolved over a period of three weeks. Subsequent investigation showed that he suffered from sickle-cell haemoglobin $\mathbf{C}$ disease.

Case 4.-A 15-year-old Jamaican girl with sickle-cell haemoglobin C disease developed nausea, vomiting, and left-sided abdominal pain three hours after a flight in a pressurized aircraft from Kingston to Mexico City. The symptoms persisted until, five days later, she moved to Acapulco at sea level. It is of interest that the altitude of Mexico City $(7,000 \mathrm{ft} ; 2,135 \mathrm{~m})$ is roughly equivalent to the maximum cabin altitude experienced in flight in a pressurized aircraft.

Case 5.-A 14-year-old schoolgirl from Jamaica was admitted to hospital with acute abdominal pain which started during a flight to London. It was noted that her spleen was enlarged and tender. The haemoglobin was $11.5 \mathrm{~g} / 100 \mathrm{ml}$, white cell count $11,100 / \mathrm{mm}^{3}$, and reticulocyte count $5 \cdot 6 \%$. Mild polychromasia and many target cells were noted. The sickle test was positive, and haemoglobin electrophoresis showed haemoglobins $S$ and $C$. A diagnosis of splenic infarction was made and the patient made an uneventful recovery. 
Case 6.-A 48-year-old Jamaican woman flew from Antigua to San Juan in 1959 in a small unpressurized aircraft. After one hour she developed pain in the left side of the abdomen, aggravated by movement and deep breathing; this subsided over the course of four weeks. Since 1967 she has made many flights in commercial aircraft and often experienced a mild recurrence of this pain, sometimes relieved by breathing oxygen in flight, and usually taking a few days to subside. Haemoglobin studies showed the presence of haemoglobins $\mathbf{S}$ and $\mathbf{C}$.

Case 7.-A 34-year-old Jamaican woman with sickle-cell thalassaemia developed nausea, vomiting, and a severe left-sided abdominal pain while on a flight in a pressurized aircraft between Bermuda and London. The pain subsided after four days. Before the flight her spleen tip had been palpable, but subsequently it could not be felt. She had previously flown twice in pressurized aircraft without trouble, and her return flight was uneventful.

\section{Discussion}

At a given altitude the tendency to sickling is related to the concentration of sickle haemoglobin within the red cell, which is lowest in the sickle-cell trait. Infarctive crises in this condition in unpressurized aircraft are well recognized. Sullivan (1950) described the first case of splenic infarction during flight in an 18-year-old Negro youth travelling over the Rocky Mountains, a flight requiring an altitude of 10,000 to $16,000 \mathrm{ft}(3,050$ to $4,875 \mathrm{~m}$ ) in an unpressurized aircraft. He developed nausea and pain in the left upper quadrant persisting for several days, and examination showed a large tender spleen. A positive sickle-cell test with a normal haemoglobin level suggested he was a sicklecell trait carrier, though electrophoresis was not performed.

Cooley, Peterson, Engel, and Jernigan (1954) described six cases with a triad of sickle-cell trait, splenic infarction, and high-altitude flying in unpressurized aircraft; Smith and Conley (1955) reported further cases both in patients with sickle-cell trait and in patients with sickle-cell haemoglobin $\mathrm{C}$ disease. There is no recorded incident of a sickle-cell trait carrier having an infarctive crisis as a result of flying in a pressurized aeroplane despite the many thousands who must have been at risk. However, many intending passengers are not aware that scheduled airlines, especially in Africa, still use unpressurized aircraft-for example, Case 1.

Clinically, the greatest tendency to sickling occurs in sicklecell anaemia. After multiple splenic infarcts in childhood most cases of sickle-cell anaemia develop splenic scarring, and the small fibrosed splenic remnant is no longer sensitive to the insults of high altitude. Splenomegaly persists in about $10 \%$ of adults with sickle-cell anaemia in the West Indies (Serjeant, 1970a) but such cases are usually characterized by high levels of fetal haemoglobin (Serjeant, 1970b) and they show a decreased tendency to sickling and splenic infarction. At present there are no well-documented cases of splenic infarction in sickle-cell anaemia during flight. Case 2 shows that patients with sickle-cell anaemia may suffer infarctive crises at other sites-for example, in the bones. However, this seems to be a surprisingly rare occurrence. Many patients from the sickle-cell clinic at the University Hospital of the West Indies often travel by air to the United States and an infarctive episode during flight has never been recorded.

Sickle-cell thalassaemia is commonly associated with splenomegaly. Case 7 is an example of a splenic infarction suffered in flight by a patient with this variety of sickle-cell disease. On this occasion the patient's spleen underwent some degree of "autosplenectomy," becoming impalpable after the infarction. This would presumably make her less liable to a similar incident during a subsequent flight.

\section{SICKIE-CELL HAEMOGLOBIN C DISEASE}

The greatest risk would seem to be in patients with sickle-cell haemoglobin $\mathrm{C}$ disease who, with the near-normal haemoglobin levels, have a relatively high blood viscosity. Splenomegaly is common in this disease and the sluggish splenic circulation may, during flight, be further compromised by the aircraft seat belt and prolonged immobility. Long journeys even by car or bus have been cited by Diggs (1965) as a possible precipitating cause for a sickling crisis, and a report by Canby, Carpenter, and Ellmore (1944) also refers to this. In this case a Sicilian youth of 19 with a moderately severe but unspecified sickling disorder suffered an infarct during a car journey from New York to Los Angeles which involved the crossing of the Rockies as a possible additional factor.

Splenic infarction in sickle-cell haemoglobin $\mathrm{C}$ disease has been described during a flight in commercial aircraft flying at low altitude $(4,000-6,090 \mathrm{ft} ; 1,220-1,830 \mathrm{~m})$ or using a pressurized system (Doenges, Smith, Wise, and Breitenbucher, 1954; Coleman and Furth, 1955; Rotter, Luttgents, Peterson, Stock, and Motulsky, 1956). It is often not appreciated that pressurization even in the most modern airline is still not complete; such aircraft have a "maximum differential" pressurizing system whereby the cabin altitude is related to flight altitude. For example, the Boeing 707 has a maximum cabin differential pressure of $8.6 \mathrm{lb} /$ in $^{2}\left(0.6 \mathrm{~kg} / \mathrm{cm}^{2}\right)$, sufficient to raise the atmospheric pressure at an ambient altitude of $22,500 \mathrm{ft}$ $(6,860 \mathrm{~m})\left(6.1 \mathrm{lb} / \mathrm{in}^{2} ; 0.43 \mathrm{~kg} / \mathrm{cm}^{2}\right)$ to that present at sea level $\left(14.7 \mathrm{lb} / \mathrm{in}^{2} ; 1.03 \mathrm{~kg} / \mathrm{cm}^{2}\right)$. Above this the cabin altitude rises accordingly, and most "pressurized" aircraft operate with a cabin atmosphere at an equivalent of between 5,000 and $7,000 \mathrm{ft}$ $(1,525$ and $2,135 \mathrm{~m})$ when flying at their normal cruising altitude. Cases 3-6 above are examples of patients with sickle-cell haemoglobin $\mathrm{C}$ disease who developed splenic infarction associated with a flight in a modern pressurized commercial aircraft.

Erlandson, Schulman, and Smith (1960) commented on the deleterious effect of altitude on the clinical course of sickle-cell disease. Diggs (1965) referred specifically to the potential danger of mountain trips as a factor precipitating a sickle crisis. Sicklecell anaemia seems to be clinically severe in Central Africa and relatively benign in the West Indies. It is possible that this difference in severity may be due to improved medical care and nutrition associated with higher social status, but the role of altitude may be relevant. Much of Central Africa is at an altitude of $5,000 \mathrm{ft}(1,525 \mathrm{~m})$, equivalent to that in a pressurized aircraft, whereas most of the Jamaican population is centred in large towns at sea level-for example, Kingston. Case 4 shows the effect of transporting a case of sickle-cell haemoglobin $\mathrm{C}$ disease from sea level to Mexico City $(7,000 \mathrm{ft} ; 2,135 \mathrm{~m})$. In this case either the air journey or the stay at altitude may have precipitated the crisis, but it is of interest that the symptoms subsided on the patient's return to sea level.

\section{RECOMMENDATIONS}

The Aerospace Medical Association (1961) recommended that passengers with sickle-cell anaemia and sickle-cell haemoglobin $\mathrm{C}$ disease should not fly. Such advice may be sound but could be severely limiting for Negro businessmen or travellers where time is important. It is preferable therefore to establish the groups with the highest risk and inform them of the dangers before travel. In our experience the most severe form of sicklecell disease, sickle-cell anaemia, seems, perhaps due to previous "autosplenectomy," to be at only slight risk when flying in pressurized aircraft. Our observations are supported by a single experiment conducted by Henderson and Thornell (1946). They submitted a volunteer patient with "active sickle-cell anaemia" to a simulated flight of two hours and 11 minutes. This included 30 minutes at $15,000 \mathrm{ft}(4,570 \mathrm{~m})$ and five minutes at $16,000 \mathrm{ft}(4,875 \mathrm{~m})$. At these altitudes the arterial oxygen pressure would only be about $40 \mathrm{~mm} \mathrm{Hg}$. When oxygen was subsequently administered for 10 minutes at $16,000 \mathrm{ft}$ $(4,875 \mathrm{~m})$ it was to make further experimental observations and apparently not at the request of the patient. Though an increased number of circulating sickled cells were observed during 
the "flight" they reported that the patient withstood the lowered oxygen tension better than both individuals with the sickle-cell trait and normal control subjects.

Findlay, Boulter, and MacGibbon (1947) demonstrated invivo sickling in three sickle-cell trait carriers flying at $15,000 \mathrm{ft}$ $(4,570 \mathrm{~m})$ and they advised that oxygen should be carried in all aeroplanes in which Africans are passengers. The sickle-cell trait is no longer an important risk in most commercial flights, but if, as on certain African routes, a Negro traveller must take an unpressurized aircraft it would be wise to ascertain the sickling status before departure. Under these exceptional circumstances even the relatively benign sickle-cell trait carrier should seek surface transport, unless at over $7,000 \mathrm{ft}(2,135 \mathrm{~m})$ oxygen can be continuously administered.

Patients with sickle-cell haemoglobin $\mathrm{C}$ disease seem to be at greatest risk and they should if possible completely avoid air travel. While continuous oxygen therapy could be made available in exceptional circumstances, it is not feasible as a normal commercial practice.

However, cases may be so benign as to be unsuspected until an in-flight incident occurs. The only way to avoid this situation would be to set up a screening system available to all Negro travellers, which would detect not only the presence of sickle haemoglobin but specifically cases of undiagnosed sickle-cell haemoglobin $\mathrm{C}$ disease, sickle-cell thalassaemia, and the unusual clinically benign cases of sickle-cell anaemia with persistent splenomegaly. The classical case of sickle-cell anaemia will almost certainly be already diagnosed. While air travel, even in pressurized aircraft, cannot be recommended for these latter patients it would seem that the risk of infarction in flight is surprisingly small.

\section{AIRCREW FITNESS}

Finally, though the foregoing reports relate to problems for airline passengers the question of sickle-cell disease and aircrew fitness needs careful consideration. Clearly, patients with the more severe sickle-cell disorders, including sickle-cell haemoglobin $\mathrm{C}$ disease, should not be allowed to fly as aircrew, and this attitude seems to be generally accepted. There is currently less agreement on the suitability for aircrew duties of sickle-cell trait carriers. Lewis (1970) suggested that such patients should not enter a career involving airline flying, but that those aircrew already trained who are subsequently found to have the sicklecell trait should be allowed to continue flying under medical supervision.

There seems to be little logic in this argument, which presumably advocates rejection of new entrants with the sickle-cell trait on the grounds that they may represent a safety risk. To retain those already trained, though superficially humane, seems to ignore this implied risk, and it is difficult to reconcile the two attitudes. It would seem most important that some firm, lasting, and internationally acceptable policy be defined on this subject by the authorities responsible for aircrew licensing.

We are grateful to Dr. G. Blanshard, Dr. R. P. Britt, and Wing Commander F. E. S. Keiller for permission to report cases under their care.

\section{References}

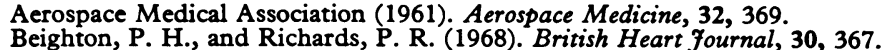
Canby, C. B., Carpenter, G., and Ellmore, L. F. (1944). Archives of Surgery, Canby, C. B.

Coleman, W. A., and Furth, F. W. (1956). Archives of Internal Medicine, 98, 247 .

Cooley, J. C., Peterson, W. L., Engel, C. E., and Jernigan, J. P. (1954). Fournal of the American Medical Association, 154, 111.

Diggs, L. W. (1965). American fournal of Clinical Pathology, 44, 1.

Doenges, J. P., Smith, E. W., Wise, S. P., and Breitenbucher, R. B. (1954). fournal of the American Medical Association, 156, 955.

Erlandson, M. E., Schulman, I., and Smith, C. H. (1960). Pediatrics, 25, 629.

Findlay, G. M., Boulter, E. A., and MacGibbon, C. B. (1947). Fournal of the Royal Army Medical Corps, 89, 138.

Henderson, A. B., and Thornell, H. E. (1946). Fournal of Laboratory and Clinical Medicine, 31, 769.

Jones, S. R., Binder, R. A., and Donowho, E. M. (1970). New England fournal of Medicine, 282, 323.

Konotey Ahulu, F. I. D. (1969). Lancet, 1, 267.

Lewis. R. A. (1970). Sickle States: Clinical Features in West Africans. Accra, Ghana Universities Press.

McCormick, W. F. (1961). American fournal of the Medical Sciences, 241, 329. Motter, R., Luttgens, W. F., Peterson, W. C., Stock, A. E., and Motulsky,

A. G. (1956). Annals of Internal Medicine, 44, 257.
Serjeant, G. R. (1970a). West Indian Medical fournal, 19, 1.

Serjeant, G. R. (1970b). British Fournal of Haematology, 19, 635.

Sluijter, M. E. (1969). In Recent Advances in Aerospace Medicine, ed. D. E. Busby. Dordrecht, the Netherlands, Reidel.

Smith, E. W., and Conley, C. L. (1955). Bulletin of the Fohns Hopkins Hospital, 96, 35 .

Sullivan, B. H. (1950). Annals of Internal Medicine, 32, 338.

Thompson, G. R. (1963). British Medical fournal, 2, 976.

\title{
Transrectal Prostatic Biopsy
}

\author{
W. F. HENDRY, J. P. WILLIAMS
}

British Medical fournal, 1971, 4, 595-597

\section{Introduction}

\section{Summary}

Transrectal prostatic biopsy specimens were taken from 218 patients with prostatic symptoms-138 by the Franzen aspiration technique without anaesthesia as outpatients and 80 by the Silverman technique under general anaesthesia. A reliable diagnosis was obtained in $82 \%$ of the former and $95 \%$ of the latter.

St. Peter's Hospitals and Institute of Urology, London W.C.2 W. F. HENDRY, CH.M., F.R.C.s., Senior Surgical Registrar J. P. WILLIAMS, M.CHIR., F.R.C.S., Senior Lecturer

It is generally agreed that the diagnosis of carcinoma of the prostate should be confirmed microscopically before treatment is started. Though an extensive transurethral prostatectomy will nearly always confirm the diagnosis (Denton et al., 1967), there is good evidence that a specimen taken for biopsy by needle is more reliable than a linnited specimen obtained via the urethra (Purser et al., 1967). Estimates of the accuracy of needle biopsy, however, have ranged from 50 to $90 \%$ (Kaufman et al., 1954) up to 95\% (Rinker and Shuman, 1952; Bianchi, 1956).

While the perineal route has usually been used for taking tissue from the prostate by needle, Astraldi (1937) first described good results with the transrectal approach, and noted minimal morbidity in a series of more than 100 cases. The safety and efficiency of this approach has since been confirmed by Grabstald and Elliott (1953), Grabstald (1954, 1956), Graham (1958), and Daves et al. (1961). 